\title{
Agronomic Performance of Different Open-Pollinated Beetroot Genotypes Grown Under Organic Farming Conditions
}

\author{
Khadijeh Yasaminshirazi ${ }^{1, *}$, Jens Hartung ${ }^{2}$, René Groenen ${ }^{3}$, Thomas Heinze ${ }^{4}$, \\ Michael Fleck ${ }^{4}\left(\mathbb{D}\right.$, Sabine Zikeli ${ }^{5}$ and Simone Graeff-Hoenninger ${ }^{1}(\mathbb{D})$ \\ 1 Cropping Systems and Modelling, Institute of Crop Science, University of Hohenheim, Fruwirthstr. 23, \\ 70599 Stuttgart, Germany; simone.graeff@uni-hohenheim.de \\ 2 Department of Biostatistics, Institute of Crop Science, University of Hohenheim, Fruwirthstr. 23, 70599 \\ Stuttgart, Germany; jens.hartung@uni-hohenheim.de \\ 3 De Beersche Hoeve, Baesterdijk 5, 5091 RA Oostelbeers, The Netherlands; groengraaf@gmail.com \\ 4 Kultursaat e.V., Kronstraße 24, 61209 Echzell, Germany; thomas.heinze@kultursaat.org (T.H.); \\ michael.fleck@kultursaat.org (M.F.) \\ 5 Center for Organic Farming, University of Hohenheim, Fruwirthstr. 14-16, 70599 Stuttgart, Germany; \\ zikeli@uni-hohenheim.de \\ * Correspondence: khadijeh.yasaminshirazi@uni-hohenheim.de; Tel.: +49-711-459-24186
}

Received: 15 May 2020; Accepted: 5 June 2020; Published: 8 June 2020

\begin{abstract}
Due to the increase of the organic cultivation of beetroot and its growing importance as a functional food, the potential advantages of open-pollinated genotypes as an alternative for F1 hybrid genotypes has been investigated. In this regard, six field experiments were carried out in 2017 and 2018 in three different locations to investigate the agronomic potential of new and existing open-pollinated genotypes of beetroot and their performance under the specific conditions of organic agriculture. Fifteen beetroot genotypes, including one F1 hybrid as a commercial control and one breeding line, were compared regarding their total and marketable yield, individual beet weight, diameter of beet, and leaves-growth-base width. Furthermore, five randomly selected beetroots meeting common marketable criteria were evaluated optically with regard to skin smoothness, corky surface, root tail, scab incidence, and uniformity. Results of this study indicated a significant impact of genotype on eight of the assessed traits. The cylindrical-shaped genotype, Carillon RZ, demonstrated significantly higher total and marketable yields, with $53.28 \pm 3.34 \mathrm{t} \mathrm{ha}^{-1}$ and $44.96 \pm 3.50 \mathrm{t} \mathrm{ha} \mathrm{h}^{-1}$, respectively, compared to the yellow-colored genotype, Burpees Golden, which obtained the lowest total yield, $36.06 \pm 3.38 \mathrm{t} \mathrm{ha}^{-1}$, and marketable yield, $27.92 \pm 3.55 \mathrm{t} \mathrm{ha}^{-1}$. Moreover, the comparison of the open-pollinated genotypes with the F1 hybrid, Monty RZ F1, revealed that except for the traits yield, scab, and uniformity, the open-pollinated genotypes indicated desirable competitive outcomes and thus offer suitable alternatives for organic cropping systems. Overall, the observed genetic variability can be beneficial for breeding and food product development.
\end{abstract}

Keywords: beetroot; open-pollinated genotype; organic farming; total yield; marketable yield; beet morphology

\section{Introduction}

With an average of $15 \%$ annual increase in cultivation area and a total of approximately 1900 ha (2018), beetroot is a commercially important vegetable in Germany [1]. The high demand for beetroot is also reflected in the quantities purchased per household in Germany, which amounted in 2018 to two kilograms [2]. Approximately $40 \%$ of the beetroot produced in Germany grows on organic farmlands, 
which makes this vegetable a typical organic product [3]. Beetroot is often offered fresh, as well as pre-cooked and vacuum-packed [1].

Beetroot (Beta vulgaris L. ssp. vulgaris) belongs to the Chenopodiaceae family. It is considered a classic winter vegetable and its pollination is naturally carried out by wind [4]. In the first year, the beet is formed by the thickening of the shoot axis section below the cotyledons. Depending on the genotype, the beet has a round or cylindrical shape. For seed production, beets are replanted in the second year. Recently, with the classification of beetroot as a functional food [5], the importance of this vegetable has further increased. The term functional food generally covers those foods showing health-promoting and disease-preventing benefits due to their nutritive value [6]. Moreover, relatively easy cultivation and good storability without the need for costly storage equipment has increased farmers' as well as the food industry's interest in beetroot production [7]. In addition, information on the morphology of the root crops, especially the shape and size of the storage organ, due to its impact on processing, consumer choice, and transportation, is necessary [8] and consequently it can lead to quality improvement of the crop products [9].

The demand for organic products is constantly increasing [10]. According to different studies which compared the quality of organic and conventional food products, a higher amount of health-benefiting compounds and lower amounts of harmful components were reported in organically produced foods [11-14]. For instance, the study of Bavec et al. [10] depicted that the amount of total sugar content, total phenol content, and total antioxidant activity was higher in organically grown beetroot (cv. Rote Kugel) compared to those which were cultivated under conventional conditions. Moreover, in terms of sensory quality, red beetroot grown under organic conditions had a better taste and smell [15]. In order to meet the requirements and comply with the values of organic agriculture, cultivars need to be adapted to the agronomic conditions of organic farming [16]. One of the main criteria for organic crops is their ability to reproduce. Hence, open-pollinating genotypes are of major interest as the farmers can multiply the seeds themselves instead of depending on external inputs [17,18]. The other important principle of organic plant breeding is that the characteristics of the selected plant can be passed on homogeneously to the next generations [19]. Despite the fact that the F1 hybrids are known to be homogeneous genotypes, the resulting offspring are typically heterogeneous [20]. F1 hybrids are referred to those seeds or plants of the first filial generation which result from a cross-mating of different parental types [21]. Furthermore, the F1 hybrid genotypes of beetroot show a narrower genetic base in comparison with open-pollinated cultivars [22]. Consequently, the open-pollinating cultivars represent more advantages for the use in organic farming compared to F1 hybrids.

The objectives of the present study were to assess the agronomic performance of 14 new and existing open-pollinated beetroot genotypes, including one breeding line, and one F1 hybrid under the specific conditions of organic farming. The genotypes were evaluated for their genetic yield potential and morphological traits and their suitability and stability in different years and locations.

\section{Materials and Methods}

\subsection{Field Experiments and Plant Materials}

Field trials were carried out in 2017 and 2018, at three different locations. Two of the locations were the on-farm breeding locations coordinated by Kultursaat e.V.: De Beersche Hoeve (Oostelbeers, Netherlands), and Horticulture station Heinze (Bingenheim, Hessia, Germany). The third location was the research station for organic farming Kleinhohenheim (University of Hohenheim, Stuttgart, Baden-Wuerttemberg, Germany).

The on-farm breeding location De Beersche Hoeve is located at a latitude of $51^{\circ} 28^{\prime} 47 \mathrm{~N}$, longitude of $5^{\circ} 15^{\prime} 35 \mathrm{E}$, and $17 \mathrm{~m}$ above sea level. In 2017, during the growth period (July-October), the mean temperature was $16^{\circ} \mathrm{C}$ and the mean precipitation reached $47 \mathrm{~mm}$. In 2018 , the mean temperature and precipitation during the growth period (June to September) were $16.5^{\circ} \mathrm{C}$ and $27.7 \mathrm{~mm}$, respectively. The soil texture is fine sand with a low clay content. 
The Horticulture station Heinze $\left(50^{\circ} 22^{\prime} 28 \mathrm{~N}, 8^{\circ} 53^{\prime} 45 \mathrm{E}\right)$ is located at an altitude of $129 \mathrm{~m}$ above sea level. In 2017, during the growth period (June to September), the mean temperature was $16.2^{\circ} \mathrm{C}$ and the mean rainfall was $53.5 \mathrm{~mm}$. In 2018, the mean temperature and the precipitation during June to September were $20.7^{\circ} \mathrm{C}$ and $24.1 \mathrm{~mm}$, respectively. The soil texture is clayey loam.

The research station Kleinhohenheim is located at a latitude of $48^{\circ} 44^{\prime} 14 \mathrm{~N}$, longitude $9^{\circ} 12^{\prime} 01 \mathrm{E}$, and $430 \mathrm{~m}$ above the sea level. In 2017, during the months July to October, the mean precipitation was $77.42 \mathrm{~mm}$ and the mean temperature $17.6^{\circ} \mathrm{C}$. In 2018 , the mean rainfall reached to $38.2 \mathrm{~mm}$ and the mean temperature was $19.0^{\circ} \mathrm{C}$ between June and September. The soil texture is considered as loess to loamy clay.

Total monthly precipitation as well as monthly mean temperature of all three research stations during the experimental period in 2017 and 2018 are shown in Figure 1A-C.

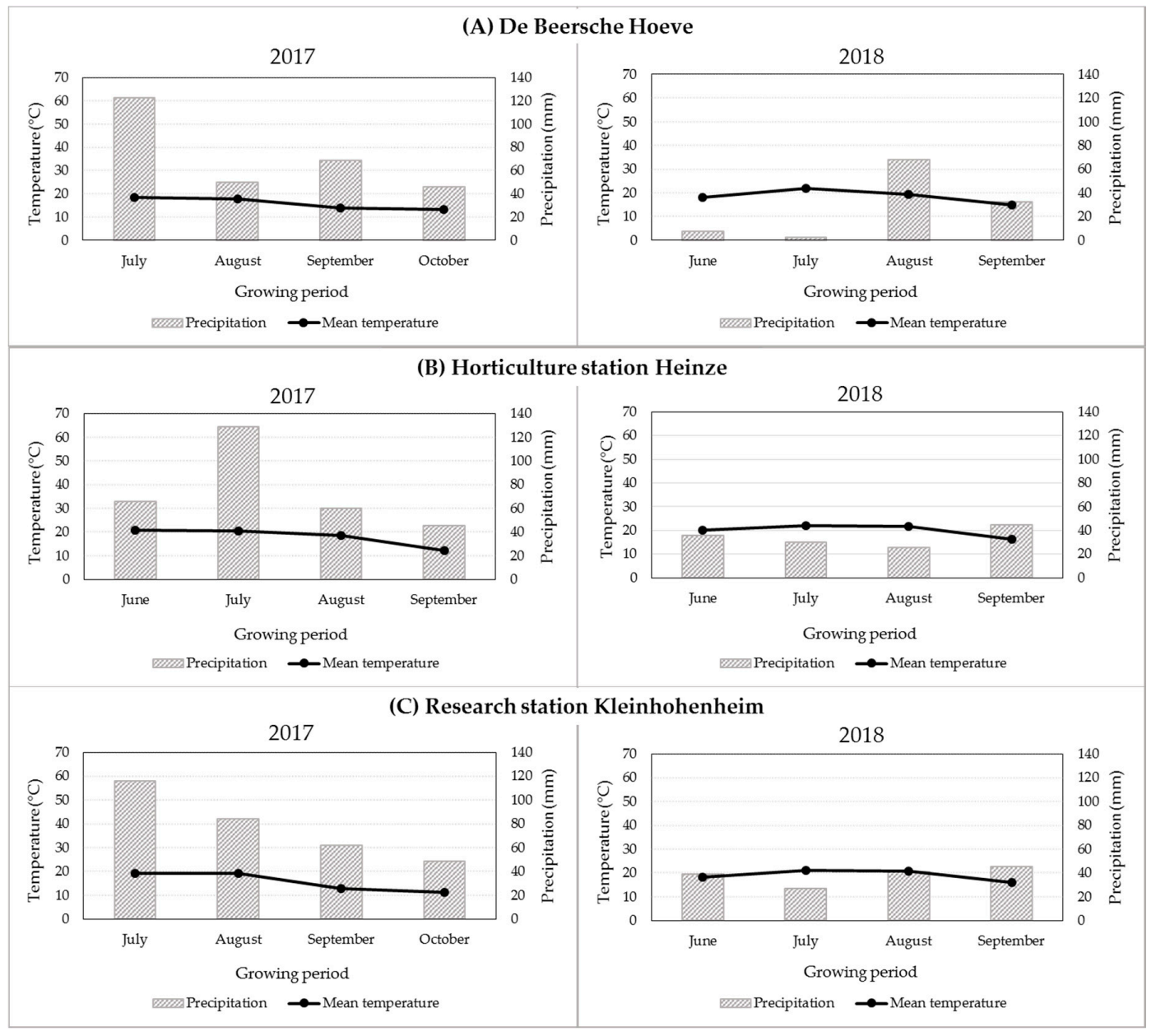

Figure 1. Total monthly precipitation $(\mathrm{mm})$ and monthly mean temperature $\left({ }^{\circ} \mathrm{C}\right)$ of the on-farm breeding station De Beersche Hoeve (the Netherlands) (A), the Horticulture station Heinze (Germany (B), and research station Kleinhohenheim (Germany) (C) during the experimental period in 2017 and 2018.

All field trials were conducted under organic farming conditions in accordance with the European Commission's main regulations for organic farming. Briefly, no synthetic fertilizer was applied to the soil. Pests and disease control were done using biological controls. Frequent mechanical or manual weeding was conducted to suppress the weeds. The genotypes were allocated to the six field trials according to a non-resolvable row column design or a randomized complete block design (Table A1). In 2017, on each on-farm breeding location 30, and in Kleinhohenheim, 40 open pollinating genotypes were cultivated in three field replicates. In 2018, 16 open pollinating genotypes were assessed on each on-farm breeding location, while 36 genotypes were tested in Kleinhohenheim. Over both years 
15 genotypes were assessed on all locations forming the orthogonal core of the experiment. Note that data from all genotypes were analyzed, but the presented results were limited to the 15 genotypes which occurred in all location-by-year combinations. The 15 investigated genotypes were 13 red-colored beets: Akela, Betina, Bona, Bordo AS, BoRu1, Carillon RZ, Cervena Kulata, Detroit 3, Jawor, Monty RZ F1, Nobol, Nochowski, Ronjana, one white genotype, Sniezna Kula, and one yellow-colored beet, Burpees Golden. BoRu1 is a breeding line of the breeding organization, Kultursaat e.V., which was used in order to assess its market potential as a new open-pollinated genotype. Table 1 depicts the information regarding shape and color of the beets as well as the seed origin of the 15 selected genotypes. The seeds needed for all six trials were ordered in spring 2017 and stored in a dark and dry place until the sowing day.

Table 1. List of the 15 studied beetroot genotypes (beet shape and color, and seed origin).

\begin{tabular}{cccc}
\hline Genotype & Beet Color & Shape & Seed Origin \\
\hline Akela RZ & red & spherical & Rijk Zwaan \\
Betina & red & spherical & Moravo Seeds (CZ) \\
Bona & red & spherical & Moravo Seeds (CZ) \\
Bordo AS & red & spherical & Seklos (LT) \\
BoRu1 & red & spherical & Kultursaat e.V. \\
Burpees Golden & yellow & spherical & Bingenheimer S. AG \\
Carillon RZ & red & cylindrical & Rijk Zwaan \\
Cervena Kulata & red & spherical & Moravo Seeds (CZ) \\
Detroit 3 & red & spherical & Caillard \\
Jawor & red & spherical & Snówidza (PL) \\
Monty RZ F1 & red & spherical & Rijk Zwaan \\
Nobol & red & spherical & Vilmorin (PL) \\
Nochowski & red & spherical & Spójnia (PL) \\
Ronjana & red & spherical & Bingenheimer S. AG \\
Sniezna Kula & white & spherical & Torseed (PL) \\
\hline 1 Excet the ged & rityper
\end{tabular}

${ }^{1}$ Except the genotype Monty RZ F1, all the other genotypes are open-pollinated.

At De Beersche Hoeve, the field experiments were conducted as row-column design in 2017 and as randomized complete block design in 2018. In the first trial year, the field was fertilized with compost equivalent to $60 \mathrm{~kg} \mathrm{~N} \mathrm{ha}^{-1}$ and in the second year, compost equivalent to $90 \mathrm{~kg} \mathrm{~N} \mathrm{ha}^{-1}$ was incorporated into the soil. The preceding crops were clover grass and Romanesco broccoli in 2017 and 2018, respectively. The field was ploughed two months before each experiment to a depth of $20 \mathrm{~cm}$. Harrowing was done twice before sowing to a depth of approximately $3 \mathrm{~cm}$. The plot size was set as $9 \mathrm{~m}^{2}$ with three cultivation rows per plot and an inter-row spacing of $50 \mathrm{~cm}$. In the first field trial, sowing was conducted using a precision seed drill on 14 July 2017, and the harvest was done manually on 26 October 2017. In 2018, the beetroots were seeded on 12 June 2018 and harvested on 27 September 2018. In both trials, weed control was done manually and mechanically by hoeing.

At the Horticulture station Heinze, the field experiment was carried out as randomized complete block design in both 2017 and 2018 with three replicates. In 2017, the preceding crop was broccoli, while in 2018, the preceding crop was carrot. In both experimental years, no fertilizer was applied to the field. The field was prepared by ploughing in autumn to a depth of $25 \mathrm{~cm}$ and harrowed three months before sowing to a depth of $8 \mathrm{~cm}$. The plot size was $8.75 \mathrm{~m}^{2}$ with three rows per plot and an inter-row spacing of $42 \mathrm{~cm}$. In 2017, the sowing took place on 08 June 2017 using a hand-sowing machine and the harvest was carried out manually on 30 September 2017. In 2018, the trial started on 09 June 2018 and the beetroots were harvested on 10 September 2018. Weeding was performed by hand and by a wheel hoe.

At the research station Kleinhohenheim, the experimental design was set up as row-column with three replicates in 2017 and as non-resolvable block design, with a block size of ten and a number of 
treatment of 36, in 2018, with three replicates for 32 genotypes and six replicates for four genotypes. The unequal replications were due to the point that the four genotypes with six replicates belonged to breeding lines, and their performance in the field was unknown. Therefore, in order to have sufficient samples, more replicates were considered for them. In 2017, the preceding crop was clover grass which was considered as green manure, and additionally, the field was fertilized with Vinasse, equivalent to $8.3 \mathrm{~kg} \mathrm{~N} \mathrm{ha}^{-1}$, one month after seeding. In 2018, no additional fertilizer was used due to the N fixation by the pre-crop clover grass. In January 2017, the field was ploughed to a depth of $20 \mathrm{~cm}$ and the seed bed was prepared using a rotary harrow to a depth of $6 \mathrm{~cm}$. In the second year of the experiment, ploughing was carried out in January 2018 and harrowing was done about 40 days before sowing. The plot size was $14 \mathrm{~m}^{2}$ with four rows per plot and an inter-row spacing of $35 \mathrm{~cm}$. In the first experiment, sowing was done on 06 July 2017 and beetroots were harvested manually on 16 October 2017. The sowing and harvest date in the second field trial was on 06 June 2018 and 10 September 2018, respectively. In both years, sowing was conducted using a pneumatic single-seed drill. Inter-row weed control was performed manually and intra-row weeding was carried out mechanically by hoeing.

\subsection{Agronomic Traits}

\subsubsection{Total and Marketable Yield}

After the manual harvest of the beetroots, the stems and leaves were cut by hand and immediately the beets' fresh-weight was measured. For the determination of the marketable yield, the harvested beetroots were sorted based on our defined diameter (between 5 and $13 \mathrm{~cm}$ ) and quality (without any deformation and notable damage).

\subsubsection{Diameter of Beet and Width of Leaves-Growth-Base}

The average beet size of each genotype as well as the width of the leaves-growth-base was determined by using a Vernier caliper. Five randomly selected marketable beetroots of each plot were measured at the widest part of the beet and at the leaves-growth-base.

\subsubsection{Individual Beet Weight}

Five randomly selected marketable beets were weighed individually, directly after the harvest, to estimate the average weight of beets of the investigated genotypes and to understand if the yield consisted of a lot of small beets or of bigger and fewer beets per defined area.

\subsubsection{Beet Evaluation}

With respect to the remarkable influence of the beet morphology and disease resistance of different genotypes on the quality and customer acceptance, the following five traits were evaluated, smoothness of skin, corky surface, root tail, scab (Streptomyces scabies), and uniformity (Table 2). In this regard, the marketable beetroots were examined optically using a 1-9 scale. Smoothness and corky surface of beet skin, as well as scab incidence, are among the traits affecting the attractiveness of the beets especially for the fresh market. Information on root tail and uniformity is particularly important for the use of the beet for processing purposes.

Table 2. Evaluation specification of five important outer traits of beetroot using a 1-9 scale.

\begin{tabular}{cccccc}
\hline Scale & Smoothness of Skin & Corky Surface & Root Tail & Scab & Uniformity \\
\hline 1 & very rough & no/very little & not detached & no infestation & very low \\
3 & rough & little & little detached & little & \\
5 & average & average & average & average & average \\
7 & smooth & much & detached & many & \\
9 & very smooth & very much & very detached & very much & very high \\
\hline
\end{tabular}




\subsection{Statistical Analysis}

According to the design of the experiment, the data was analyzed by the following linear mixed model:

$$
y_{i j k l m n}=\mu+b_{l j k}+r_{m j k}+c_{n j k}+a_{j}+l_{k}+\tau_{i}+(a l)_{j k}+(\tau a)_{i j}+(\tau l)_{i k}+(\tau a l)_{i j k}+e_{i j k l m n},
$$

where $a_{j}$ and $l_{k}$ are the fixed effects of the $j$-th year and the $k$-th location. $b_{l j k}, r_{m j k}$, and $c_{n j k}$ are the random effect of the $l$-th block, $m$-th row, and $n$-th column within a year-by-location combination. Note that row and column effects were only fitted for row-column designs. Further note that block effects were only fitted if the design has blocks. Dummy variables were used to block out these effects for all other experiments. $\tau_{i}$ is the fixed effect of the $i$-th genotype. $(a l)_{j k}$ is the fixed interaction effect of the $j$-th year and the $k$-th location. $(\tau a)_{i j}(\tau l)_{i k}$, and $(\tau a l)_{i j k}$ are the random interactions between the corresponding main effects. $e_{i j k l m n}$ is the error of $y_{i j k l m n}$ with year-by-location specific error variance. The assumptions of normality and homogeneous variances of residuals were checked graphically. If required, a logarithmic transformation of the data was used prior to analysis and results were back-transformed for presentation purpose only. Standard errors were back-transformed using the delta method. Depending on the significance of fixed effects, mean comparisons were done for the highest significant interaction term of all factors using Fisher's Least Significant Difference (LSD) test [23]. Means (or medians in case of back-transformed values) plus minus standard error of the mean (approximated standard error of the median) were presented. A letter display was used to present significant differences between means or medians [23]. Means followed by at least one identical letter were not significantly different from each other.

\section{Results and Discussion}

The statistical analysis showed that all investigated traits except the root tail and scab incidence were significantly influenced by the genotype $(p<0.05)$. This demonstrated a high variability between the genotypes regarding the agronomic traits. In order to assess the performance of different genotypes under different environmental and climatic conditions, the influence of location and experimental year on different agronomic traits was taken into account, as well. In accordance with the statistical analysis, all traits except scab, and leaves-growth-base width and individual beet weight were significantly influenced by the interaction of location $\times$ year $(p<0.05)$. Scab incidence was neither affected by year nor by location. In terms of leaves-growth-base, the results of the analysis of variance (ANOVA) showed a significant effect of year $(p<0.05)$ and individual beet weight was significantly impacted by both year and location. Outcomes of the ANOVA of the investigated agronomic traits are presented in Tables 3 and 4 . 
Table 3. Mean values and analysis of variance (ANOVA) of results of total yield ( $\mathrm{tha}^{-1}$ ), marketable yield ( $\mathrm{t}$ ha ${ }^{-1}$ ), beet diameter (mm), leaves-growth-base width (mm), and individual beet weight (g) of 15 different genotypes of beetroot grown in three research stations within the trial year 2017 and 2018 . Results represent the mean values \pm standard error. Means followed by at least one identical letter were not significantly different from each other.

\begin{tabular}{|c|c|c|c|c|c|}
\hline Genotype & Total Yield (t ha $\left.{ }^{-1}\right)$ & Marketable Yield (t ha-1) & Beet Diameter (mm) & $\begin{array}{c}\text { Leaves-Growth-Base } \\
\text { Width (mm) }\end{array}$ & $\begin{array}{l}\text { Individual Beet Weight } \\
\text { (g) }\end{array}$ \\
\hline Akela & $49.56^{\mathrm{abc}} \pm 3.34$ & $39.37^{\mathrm{abc}} \pm 3.50$ & $78.40^{\mathrm{a}} \pm 0.31$ & $27.78^{\text {egh }} \pm 1.83$ & $252.54^{\mathrm{ac}} \pm 17.42$ \\
\hline Betina & $48.11^{\text {ad }} \pm 3.34$ & $34.55^{\mathrm{cd}} \pm 3.50$ & $80.59^{a} \pm 0.31$ & $37.78^{b} \pm 1.83$ & $266.44^{\mathrm{ac}} \pm 17.42$ \\
\hline Bona & $50.41^{\mathrm{abc}} \pm 3.47$ & $39.64^{\mathrm{abc}} \pm 3.54$ & $80.29^{a} \pm 0.31$ & $32.49^{\text {cde }} \pm 1.86$ & $279.01^{\mathrm{a}} \pm 17.42$ \\
\hline Bordo AS & $50.34^{a b c} \pm 3.97$ & $42.29^{\mathrm{ac}} \pm 4.17$ & $81.50^{\mathrm{a}} \pm 0.31$ & $36.10^{b c} \pm 1.83$ & $283.33^{\mathrm{a}} \pm 17.42$ \\
\hline BoRu1 & $46.73^{\mathrm{ad}} \pm 3.34$ & $37.44^{\mathrm{ad}} \pm 3.50$ & $78.51^{\mathrm{a}} \pm 0.31$ & $25.22^{\mathrm{gh}} \pm 1.83$ & $252.56^{\mathrm{ac}} \pm 17.42$ \\
\hline Burpees Golden & $36.06^{\mathrm{e}} \pm 3.38$ & $27.92^{\mathrm{d}} \pm 3.55$ & $71.25^{b} \pm 0.31$ & $27.52^{\text {egh }} \pm 1.83$ & $214.71^{\mathrm{c}} \pm 17.42$ \\
\hline Carillon RZ & $53.28^{\mathrm{a}} \pm 3.34$ & $44.96^{\mathrm{a}} \pm 3.50$ & $48.54^{c} \pm 0.31$ & $23.63^{h} \pm 1.83$ & $239.87^{\mathrm{ac}} \pm 17.42$ \\
\hline Detroit 3 & $46.35^{\text {ad }} \pm 3.34$ & $33.28^{\mathrm{cd}} \pm 3.50$ & $80.55^{\mathrm{a}} \pm 0.31$ & $27.83^{\text {egh }} \pm 1.83$ & $266.90^{\mathrm{ab}} \pm 17.42$ \\
\hline Jawor & $46.02^{\mathrm{ad}} \pm 3.34$ & $35.98^{\mathrm{ad}} \pm 3.50$ & $80.04^{\mathrm{a}} \pm 0.31$ & $32.58^{\text {bde }} \pm 1.83$ & $258.66^{\mathrm{ac}} \pm 17.42$ \\
\hline Monty RZ F1 & $51.42^{\mathrm{ac}} \pm 3.34$ & $39.96^{a b c} \pm 3.50$ & $76.99^{a b} \pm 0.31$ & $32.44^{\text {cde }} \pm 1.83$ & $258.56^{\mathrm{ac}} \pm 17.42$ \\
\hline Nobol & $40.15^{\text {de }} \pm 3.34$ & $31.16^{\mathrm{bd}} \pm 3.50$ & $76.31^{\mathrm{ab}} \pm 0.31$ & $25.78^{\text {fgh }} \pm 1.83$ & $221.77^{b c} \pm 17.42$ \\
\hline Nochowski & $43.44^{\text {cde }} \pm 3.34$ & $32.17^{\mathrm{cd}} \pm 3.50$ & $79.08^{a} \pm 0.31$ & $43.14^{\mathrm{a}} \pm 1.40$ & $267.27^{\mathrm{ab}} \pm 17.42$ \\
\hline Ronjana & $42.72^{\text {bde }} \pm 3.39$ & $33.21^{\mathrm{cd}} \pm 3.52$ & $75.93^{\mathrm{ab}} \pm 0.31$ & $30.88^{\text {def }} \pm 1.40$ & $252.89^{a c} \pm 17.42$ \\
\hline Sniezna Kula & $49.70^{\mathrm{abc}} \pm 3.34$ & $35.60^{\mathrm{ad}} \pm 3.50$ & $79.43^{a} \pm 0.31$ & $29.21^{\mathrm{dg}} \pm 1.41$ & $265.87^{\mathrm{ac}} \pm 17.42$ \\
\hline Factor & \multicolumn{5}{|c|}{$p$-value of the F-test of the corresponding factor } \\
\hline Year & n.s. & 0.0259 & $<0.0001$ & $<0.0001$ & 0.0034 \\
\hline Genotype & 0.0013 & 0.0262 & $<0.0001$ & $<0.0001$ & 0.0002 \\
\hline Location $\times$ year & 0.0005 & $<0.0001$ & $<0.0001$ & n.s. & n.s. \\
\hline
\end{tabular}


Table 4. Mean values and analysis of variance (ANOVA) of results of the evaluation of beet regarding the skin smoothness, corky surface, root tail, scab, and uniformity of 15 different genotypes of beetroot grown in three research stations within the trial year 2017 and 2018, using 1-9 scale. Results represent the mean values \pm standard error. Means followed by at least one identical letter were not significantly different from each other.

\begin{tabular}{|c|c|c|c|c|c|}
\hline Genotype & $\begin{array}{c}\text { Smoothness of } \\
\text { Skin }\end{array}$ & Corky Surface & Root Tail & Scab & Uniformity \\
\hline Akela & $5.66^{\mathrm{abcd}} \pm 0.40$ & $4.47^{b c} \pm 0.34$ & $6.67 \pm 0.42$ & $3.99 \pm 0.34$ & $6.16^{\mathrm{ab}} \pm 0.38$ \\
\hline Betina & $4.90^{\text {be }} \pm 0.40$ & $4.48^{b c} \pm 0.34$ & $5.32 \pm 0.42$ & $3.94 \pm 0.34$ & $6.28^{\mathrm{ac}} \pm 0.38$ \\
\hline Bona & $5.65^{\mathrm{abcd}} \pm 0.40$ & $4.43^{b c} \pm 0.34$ & $6.18 \pm 0.42$ & $4.02 \pm 0.34$ & $5.98^{\mathrm{ab}} \pm 0.38$ \\
\hline Bordo AS & $5.05^{\mathrm{ce}} \pm 0.40$ & $4.93^{b c} \pm 0.34$ & $5.65 \pm 0.42$ & $3.81 \pm 0.34$ & $5.35^{b c} \pm 0.38$ \\
\hline BoRu1 & $5.08^{\mathrm{ce}} \pm 0.40$ & $4.65^{b c} \pm 0.34$ & $6.21 \pm 0.42$ & $4.09 \pm 0.34$ & $6.16^{\mathrm{ab}} \pm 0.38$ \\
\hline Burpees Golden & 4.59 de \pm 0.40 & $4.90^{b c} \pm 0.34$ & $5.23 \pm 0.42$ & $3.50 \pm 0.35$ & $5.27^{b c} \pm 0.38$ \\
\hline Carillon RZ & $6.03^{\mathrm{abcd}} \pm 0.40$ & $4.52^{b c} \pm 0.34$ & $5.00 \pm 0.42$ & $3.20 \pm 0.34$ & $6.12^{\mathrm{ab}} \pm 0.38$ \\
\hline Cervena Kulata & $4.67^{\mathrm{de}} \pm 0.40$ & $5.04^{\mathrm{ab}} \pm 0.34$ & $5.68 \pm 0.42$ & $4.12 \pm 0.34$ & $6.23^{\mathrm{ab}} \pm 0.38$ \\
\hline Detroit 3 & $3.96^{\mathrm{e}} \pm 0.40$ & $4.34^{b c} \pm 0.34$ & $6.45 \pm 0.42$ & $3.96 \pm 0.34$ & $5.19^{b} \pm 0.38$ \\
\hline Jawor & $6.06^{\mathrm{ac}} \pm 0.22$ & $4.90^{\mathrm{bc}} \pm 0.34$ & $6.34 \pm 0.42$ & $3.80 \pm 0.34$ & $6.03^{\mathrm{ab}} \pm 0.38$ \\
\hline Monty RZ F1 & $6.0^{\mathrm{abcd}} \pm 0.22$ & $4.46^{b c} \pm 0.34$ & $5.78 \pm 0.42$ & $3.43 \pm 0.34$ & $6.61^{\mathrm{a}} \pm 0.38$ \\
\hline Nobol & $4.58^{\text {de }} \pm 0.22$ & $5.97^{\mathrm{a}} \pm 0.34$ & $6.24 \pm 0.42$ & $3.87 \pm 0.34$ & $5.67^{\mathrm{ab}} \pm 0.38$ \\
\hline Nochowski & $5.39^{\mathrm{abcd}} \pm 0.22$ & $4.08^{c} \pm 0.34$ & $5.65 \pm 0.42$ & $3.72 \pm 0.34$ & $6.15^{\mathrm{ab}} \pm 0.38$ \\
\hline Ronjana & $5.11^{\mathrm{ce}} \pm 0.22$ & $4.17^{b c} \pm 0.34$ & $6.56 \pm 0.42$ & $4.65 \pm 0.34$ & $5.84^{\mathrm{ab}} \pm 0.38$ \\
\hline Sniezna Kula & $6.35^{\mathrm{a}} \pm 0.23$ & $2.85^{\mathrm{d}} \pm 0.34$ & $5.50 \pm 0.42$ & $4.65 \pm 0.34$ & $6.65^{a} \pm 0.38$ \\
\hline Factor & \multicolumn{5}{|c|}{$p$-value of the F-test of the corresponding factor } \\
\hline Location & $<0.0001$ & 0.0002 & $<0.0001$ & n.s. ${ }^{1}$ & n.s. \\
\hline Year & n.s. & 0.0003 & n.s. & n.s. & n.s. \\
\hline Genotype & 0.0024 & 0.0002 & n.s. & n.s. & 0.0292 \\
\hline Location $\times$ year & $<0.0001$ & 0.0039 & $<0.0001$ & n.s. & $<0.0001$ \\
\hline
\end{tabular}

\subsection{Total and Marketable Yield}

The total yield ranged between $36.06 \pm 3.38 \mathrm{tha}^{-1}$ and $53.28 \pm 3.34 \mathrm{t} \mathrm{ha}^{-1}$. Among all 15 genotypes, the three highest total mean yields were noted for Carillon RZ, Monty RZ F1, and Bona with $53.28 \pm 3.34 \mathrm{tha}^{-1}, 51.42 \pm 3.34 \mathrm{t} \mathrm{ha}^{-1}$, and $50.41 \pm 3.47 \mathrm{tha}^{-1}$, respectively, which were statistically non-significantly different from each other (Table 3). On the other hand, the three genotypes, namely, Burpees Golden, Nobol, and Ronjana with $36.06 \pm 3.38 \mathrm{t} \mathrm{ha}^{-1}, 40.15 \pm 3.34 \mathrm{tha}^{-1}$, and $42.72 \pm 3.39 \mathrm{tha}^{-1}$, respectively, showed the lowest total yield (Table 3).

The marketable yield of the studied beetroot genotypes varied between $27.92 \pm 3.55 \mathrm{tha}^{-1}$ and $44.96 \pm 3.50 \mathrm{t} \mathrm{ha}^{-1}$ for the genotypes Burpees Golden and Carillon RZ, respectively, and were statistically different from each other (Table 3). Although the second-highest total yield belonged to the genotype Monty RZ F1, the same order was not seen for the marketable yield. The genotype Bordo AS, which gained the fourth-highest total yield with $50.34 \pm 3.97 \mathrm{tha}^{-1}$, had the second-highest marketable yield with $42.29 \pm 4.17 \mathrm{tha}^{-1}$, which indicated its higher share of marketable yield compared to the F1 hybrid genotype, Monty RZ F1.

The results revealed that the highest total and marketable yield belonged to the cylindrical genotype, Carillon RZ. Although the spherical shape has been better accepted in the fresh market [24], an increasing use of cylindrical shape genotypes in beetroot processing, due to the higher percentage of utilizable uniform slices in canning and slicing practices, has been reported [25]. Nevertheless, this uniformity in the top, middle, and bottom of the cylindrical-shape beets can be affected by population density and genotype [25]. There are different factors which affect the yield, such as sowing [26] and harvesting [27,28] date, water availability [29], cultivation system [30], and plant density [26]. Feller and Fink [27] stated that the effect of sowing date on the beetroot yield is significant. Takács-Hájos and Rubóczki [31] studied the differences in beetroot yield, depending on sowing date (April, July, and August), and noted that the highest yield was reached at the earliest sowing date in April. Furthermore, Akhiyarov et al. [32] reported a total yield ranging from $35.30-53.70 \mathrm{t} \mathrm{ha}^{-1}$ 
for a beetroot cultivar sown at five different dates, between the beginning of April and end of May over three years. In the current research, despite the fact that the sowing dates were either in June or July, the total yield was in a similar range as in the study of Akhiyarov et al. [32]. The study of Kikkert et al. [26] depicted that the marketable yield increased significantly with delayed harvest dates. Among all three harvest dates that were investigated for one beetroot genotype within two years, beetroots with 120 days growing period indicated a marketable yield of $48.9 \mathrm{t} \mathrm{ha}^{-1}$, while those with 100 and 80 growing days revealed a marketable yield of 44.2 and $28.7 \mathrm{t} \mathrm{ha}^{-1}$, respectively. In the present study, the range of the growing period was between 93-107 days, the marketable yield for all investigated genotypes varied between $27.92 \pm 3.55 \mathrm{t} \mathrm{ha}^{-1}$ and $44.96 \pm 3.50 \mathrm{t} \mathrm{ha}^{-1}$.

Considering the cultivation system as one of the yield influencing factors, it was reported that the yield of beetroots grown under organic cultivation systems was $75 \%$ of that for the conventional system [30]. Conventionally cultivation of seven different beetroot genotypes in Austria in 2013 showed a yield range of 25.5-32.5 tha $\mathrm{th}^{-1}$ [33]. However, in the present work, despite the fact that the beetroots were grown under organic conditions, total yields were considerably higher. Furthermore, according to Stagnari et al. [29], water stress can significantly decrease the yield of beetroot. In 2018, due to the extremely hot and dry summer in Germany, lower average yields in both locations was noted.

\subsection{Beet Diameter and Leaves-Growth-Base Width}

Except for the cylindrical genotype, Carillon RZ, which significantly had the lowest beet diameter with $48.54 \pm 0.31 \mathrm{~mm}$, the range of the beet diameter for all spherical genotypes varied between $71.25 \pm 0.31 \mathrm{~mm}$ and $81.50 \pm 0.31 \mathrm{~mm}$ belonging to Burpees Golden and Bordo AS, respectively, which were significantly different from each other (Table 3). Ijoyah et al. [34] compared the beet width of five different spherical-shape beetroot genotypes, and reported a diameter range of $3.64-7.55 \mathrm{~cm}$. Moreover, the beet diameter of the cylindrical-shaped genotype, Regulski Cylinder, which was grown organically in Poland, was $5.43 \mathrm{~cm}$ in 2006 and 2008, and $5.0 \mathrm{~cm}$ in 2009 [7], which in all cases are slightly larger than the mean beet diameter of the studied cylindrical-shape genotype in the present study. This may be due to the difference in the investigated genotype and the cultivation period, which was longer in the study of Szopińska and Gawęda [7]. The genotypes Betina and Detroit 3 with $80.59 \pm 0.31 \mathrm{~mm}$ and $80.55 \pm 0.31 \mathrm{~mm}$, respectively, had the second and third largest beet diameter. Following the yellow beetroot genotype, Burpees Golden, the cultivars Ronjana with $75.93 \pm 0.31 \mathrm{~mm}$ and Nobol with $76.31 \pm 0.31 \mathrm{~mm}$ had the smallest beet diameter (Table 3). The size of the beet can be mainly influenced by nitrogen fertilization [35] and water availability [26]. In the present work, in accordance with the outcomes of ANOVA, beet size was significantly impacted by genotype and the interaction of location $\times$ year $(p<0.0001)$. Burpees Golden, which possessed the smallest beet diameter, was noticed as the genotype with the lowest total and marketable yields. However, the same relation was not seen for the genotype Monty RZ F1, which was categorized among the smallest-sized beets, but resulted in the second-highest total and marketable yields. Based on Ugrinovic [35], among the marketable beetroots (beet diameter between 6-15 $\mathrm{cm}$ ), those with the beet diameter of 6-9 $\mathrm{cm}$ can be categorized as the first-class beets for the marketable purposes. Accordingly, all 14 spherical-shape genotypes in this study can be considered as first class beets.

The smallest leaves-growth-base width belonged to the cylindrical genotype, Carillon RZ, with $23.63 \pm 1.84 \mathrm{~mm}$, followed by the genotype Boru1 and Nobol with $25.22 \pm 1.84 \mathrm{~mm}$ and $25.78 \pm 1.84 \mathrm{~mm}$, respectively. No significant difference was observed between them (Table 3). In contrast, the genotype Nochowski with $43.14 \pm 1.84 \mathrm{~mm}$ had a significantly larger leaves-growth-base compared to all studied genotypes (Table 3), followed by Betina and Bordo AS with $37.78 \pm 1.84 \mathrm{~mm}$ and $36.21 \pm 1.84 \mathrm{~mm}$, respectively. This trait is important in the processing of beetroot, as the leaves-growth-base is included in the part which should be cut during processing. Therefore, a smaller leaves-growth-base width is desirable in order to achieve less flesh loss. According to the outcomes of this study, as the genotype demonstrated a significant effect on the leaves-growth-base width 
$(p<0.0001)$, selection of the suitable genotype, especially for processing purposes, may lead to lower waste.

\subsection{Individual Beet Weight}

According to the ANOVA, genotype, experimental year, and location influenced the weight of the beetroot. The beets weight varied between $214.71 \pm 17.42 \mathrm{~g}$ and $283.33 \pm 17.42 \mathrm{~g}$ (Table 3).

The fresh beet weight of 15 beetroot genotypes, which were sown in July in Hungary, ranged between 88.93-198.67 g, which is notably lower compared to the findings of the present study [31]. Furthermore, investigation of seven beetroot genotypes in Austria demonstrated a beet weight range of 214-366 g, in which the minimum value was similar to the results of this study but the maximum value was higher. Following the same position in beet diameter as well as the total yield, the yellow genotype, Burpees Golden, which owned the smallest beet diameter and the lowest yield, showed significantly lowest value regarding the beet weight with $214.71 \pm 17.42 \mathrm{~g}$. On the other hand, the genotype, Bordo AS, with the largest beet diameter, possessed the heaviest beets among all investigated genotypes with a mean beet weight of $283.33 \pm 17.42 \mathrm{~g}$. Specifications of the market regarding the size of the root crops have been increasing [36]. Although the agronomic factors affecting the size, such as plant density or harvest time, can be controlled, the size variation within a crop is still great [36]. Therefore, in order to achieve a comprehensive overview of the beet size, beside the beet diameter, the fresh weight of the individual beet was measured in this study. An important factor that determines beet size is the water availability during the growing period [26], as earlier sowing dates showed higher beet weights related to water supply in 15 different genotypes cultivated in Debrecen, Hungary [31]. In the current study, all the field trials were started either in June or July. In addition, the second year of the experiment was considered as an extreme climate condition due to the high temperature and low precipitation level. Therefore, considering the significant effect of the trial year on the beet weight in this study, it can be concluded that the abiotic factors impacted the beet weight.

Due to the importance of the beet size for the fresh market as well as for processing, information about the genetically determined beet size in order to select the suitable genotype for the specific utilization should be taken into account. For instance, the genotypes with beet sizes too large for use in the fresh market could be interesting for juice production or the use in the production of pre-cooked beetroot.

\subsection{Beet Evaluation}

Morphology of the beet can have a notable influence on the quality, and its attractiveness is a key factor for the fresh market [24]. It is reported [37] that besides high yield and resistance against diseases and pests, shape [38] and uniformity in color without white flecking [39] are the main criteria in the selection process of a beetroot genotype for breeding [40] and processing purposes. One of the factors which plays a key role in physiology and consequently for the quality of different plant species is drought stress [29]. Accordingly, due to the high temperature as well as low precipitation in the second year of this experiment, it can be assumed that the beet morphology has been influenced by this factor.

\subsubsection{Smoothness and Corky Surface of Beet Skin}

Evaluation of the beets revealed that the skin of the 15 studied genotypes differed significantly from rough to smooth with a range of $3.96 \pm 0.40$ to $6.35 \pm 0.40$ (Table 4). The results depicted that the white genotype, Sniezna Kula, with $6.35 \pm 0.40$, had the smoothest skin among all evaluated genotypes followed by Jawor and Carillon RZ with $6.06 \pm 0.40$ and $6.03 \pm 0.40$, respectively. There was no significant difference noted between them (Table 4). On the other hand, Detroit 3, Nobol, and Burpees Golden with $3.96 \pm 0.40,4.58 \pm 0.40$, and $4.59 \pm 0.41$, respectively, were evaluated as three genotypes with the lowest smoothness, although they were not significantly different from each other (Table 4). According to the results of the analysis of the variance showing a significant effect of genotype on skin 
smoothness $(p=0.0024)$, high variability of the beetroot genotypes regarding these characteristics can be concluded. Furthermore, the interaction of location $\times$ year significantly affected the smoothness of the beet skin as well $(p<0.0001)$.

Beetroots with lower corky skin have a more attractive appearance for the fresh market. Corky surface is resulted from the light brown stripes which are formed on the skin of the beet. Nobol, with $5.97 \pm 0.34$, had a significantly corkier surface compared to Cervena Kulata, with $5.04 \pm 0.34$, which was evaluated as the genotype with the second-corkiest surface. Contrarily, Sniezna Kula demonstrated the least corky surface with $2.85 \pm 0.34$ followed by the genotype Nochowski with $4.08 \pm 0.34$. The values were significantly different from each other (Table 4 ).

Comparing the results of the two traits, corky surface and beet skin smoothness, it can be seen that the genotype Sniezna Kula, which had the smoothest beet skin, was as well the genotype with the lowest corky surface which may be due to the point that the lower cork on the beet makes the skin smoother. Likewise, Nobol with the second-lowest skin smoothness was noted as the genotype with the highest corky surface. The study of Da Silva et al. (2006) indicated that an increase of the mean tuber weight in potato finally led to a smoother skin [41]. In the current study, the same correlation was not noted for beetroot. Furthermore, it has been stated that one of the factors which improves skin smoothness of carrots is to grow them on ridges [42]. It was reported that the incidence of carrot cavity spots is more common under the wet conditions [42] and due to the fact that the soil on ridges are often softer and dries faster [43] by reason of better aeration, carrots grown on the ridges showed less cavity spots and better root shape and skin smoothness. Similar cultivation methods may improve the skin smoothness of beetroot.

\subsubsection{Root Tail}

The beetroots were evaluated optically based on the degree of detachment of the root tail from the beet. The results showed that the genotype Akela, with $6.67 \pm 0.42$, was ranked as the genotype with the highest degree of detachment of the root tail from the beet followed by Ronjana and Detroit 3 with $6.56 \pm 0.42$ and $6.45 \pm 0.42$, respectively. The cylindrical genotype, Carillon RZ, with $5.0 \pm 0.42$, was ranked as the genotype with the lowest detachment of the root tail from the beet compared to the other studied genotypes. Although the value was not significantly different from that of the cultivars Burpees Golden and Betina, which were rated around the average level with $5.23 \pm 0.42$ and $5.32 \pm 0.42$, respectively (Table 4). There were no significant differences between genotypes analyzed (Table 4). However, the statistical analysis of the results demonstrated a significant influence of the interaction of location $\times$ year $(p<0.0001)$ on the root tail. This is in line with the findings of previous studies $[44,45]$ which noted the impact of environmental conditions, especially soil type, on the size and shape of the root vegetables. Moreover, the shape of the beetroot as well as the root tail is considered as a major factor due to the loss which may occur during processing [24]. To be more precise, the higher the degree of detachment of the root tail from the beet, the lower loss will result.

\subsubsection{Scab (Streptomyces Scabies)}

According to Table 4, scab incidence ranged between $3.20 \pm 0.34$ and $4.65 \pm 0.34$, which based on the defined 1-9 scale in Table 2, it can be concluded that all evaluated genotypes demonstrated little to average scab formation. Sniezna Kula and Ronjana, with both $4.65 \pm 0.34$, depicted the highest incidence of scab among all 15 genotypes. The cylindrical genotype, Carillon RZ, with $3.20 \pm 0.34$ and the F1 hybrid, Monty RZ F1, with $3.43 \pm 0.34$, were the most resistant genotypes to scab occurrence. There were no significant differences between the genotypes analyzed (Table 4). Scab (Streptomyces scabies) is a bacterial disease which causes warty growth on the skin and produces corky spots on the surface of different root crops, including beetroot and potato [46,47]. Despite the fact that the scab arises in all types of beet (Beta vulgaris L.), the occurrence of this corky lesion in beetroot due to the use in the fresh market as well as pre-cooked product in transparent packaging (such as glass bottles), is more undesirable compared with sugar beet which is pulped [48]. Crop rotation and ensuring the soil $\mathrm{pH}$ 
close to neutral are two major ways to prevent scab emergence [47]. A study by Lapwood et al. [48] on 12 different beetroot genotypes, including ten spherical and two cylindrical, showed that the two cylindrical genotypes were among the most resistant ones against the scab incidence. In line with these results, our research has as well depicted that regarding scab disease, the open-pollinated cylindrical genotype, Carillon RZ, is as resistant as the F1 hybrid, Monty RZ F1, which is typically known as the genotype with the highest resistance to the biotic and abiotic stressor.

\subsubsection{Uniformity}

The study showed that, based on the defined ranking, using 1-9 scale (Table 2), all 15 genotypes had an average to high uniformity. The highest uniformity was noted for the genotypes Sniezna Kula, Monty RZ F1, and Betina with $6.65 \pm 0.38,6.61 \pm 0.38$, and $6.28 \pm 0.38$, respectively. Detroit 3 with $5.19 \pm 0.38$, Burpees Golden with $5.27 \pm 0.38$, and Bordo AS with $5.35 \pm 0.38$ were scored as the genotypes with the lowest uniformity, through which the results were not significantly different from each other (Table 4). Strang et al. [49] reported a uniformity of the beet shape for Burpees Golden as 6.5 out of 10 (equivalent to 5.8 in our rating scale), which is close to the rate which has been noted in the present study. Due to the influencing factors such as growing space, and balanced and sufficient nutrients and water supply, uniformity of the beetroot in terms of shape and size is difficult to attain [26]. One of the influencing factors on the shape uniformity of the beets is uniform water supply in the soil [31]. Interim water deficiency can change the shape of the beet from the common spherical to oval or heart-shape, which is not desirable for the fresh market or processing purposes [24]. In the present study, due to the dry summer and low precipitation in 2018, it can be assumed that the lower water availability in the second year of the experiment affected the mean beet uniformity. Another major factor leading to non-uniformity in the maturity stage as well as the size of beets at harvest was reported to be the non-uniform seed germination [50] which occurs in the early stage of crop development [51,52]. Likewise, the cluster shape of the beetroot seed which results in up to three seedlings, causes the root size variability [53]. Furthermore, the distribution of the plants within the row and row width have been reported as two other factors affecting the uniformity of the plant [54]. In this regard, the study of Griepentrog et al. (2009) demonstrated the improvement of the spatial uniformity of sugar beet with the increase of row width from 32 to $50 \mathrm{~cm}$ [54]. Despite the point that the row distance width in the present study varied in all three locations $(35,42$, and $50 \mathrm{~cm})$, the effect of the location on the beet uniformity was not significant (Table 4). However, the interaction of location $\times$ year indicated a significant impact on the beet uniformity.

\subsection{Overall Outcomes}

Comparing the open-pollinated genotypes with the F1 hybrid, Monty RZ F1, indicated that in all investigated traits except for yield, scab, and uniformity, the open-pollinated genotypes revealed desirable competitive results. Additionally, with the available gene pool and selection of genotypes with preferable traits, there would be a possibility for cross-breeding in order to incorporate the outstanding characteristics into a new bred line. Considering the positive aspects of the open-pollinated genotypes for the use in organic farming, including maintaining the plant integrity and passing the plant-specific features to the next generation as well as the self-reproductive ability, the outcomes of the present study revealed the significant influence of the genotype on most of the assessed traits. Therefore, by providing information regarding the agronomic performances of different open-pollinated genotypes, the study recommends the selection of suitable genotypes for various purposes. In terms of beet uniformity as well as the persistence against the common beetroot disease, Streptomyces scabies, all studied genotypes indicated a high stability regarding the environmental conditions. Nevertheless, with the significant impact of location on total and marketable yield $(p<0.0001)$, it can be noted that the investigated genotypes may not be recommended for a broad range of environments if yield would be the only trait of interest. 
The traits, high total and marketable yield and high degree of uniformity of the breeding line, BoRu1, showed a potential for the cultivation in organic farming. However, other traits like skin smoothness and scab formation still need further improvement by further breeding efforts.

\section{Conclusions}

With investigating the performance of various beetroot genotypes in different locations, it can be concluded that due to the significant genetic variability in beetroot, selection of suitable genotypes should be aligned with the intended final utilization. The cylindrical genotype, Carillon RZ, with the highest total and marketable yield, smallest leaves-growth-base width and one of the most resistance genotype against the common beet disease, scab, can be suggested as a potential genotype with outstanding characteristics to farmers for cultivation in organic farming. Finally, this study only indicated the agronomic traits of the genotypes and the related impact of environmental conditions, therefore, for the application of the investigated genotypes in different sections, the sensory quality as well as the amount of the health-promoting compounds, should be additionally taken into account.

Author Contributions: Conceptualization, K.Y. and S.G.-H.; software, K.Y. and J.H.; formal analysis, K.Y. and J.H.; investigation, K.Y., R.G. and T.H.; writing —original draft preparation, K.Y.; writing-review and editing, S.G.-H., J.H., S.Z.; supervision, S.G.-H.; project administration, S.G.-H. and M.F.; funding acquisition, S.G.-H. and M.F. All authors have read and agreed to the published version of the manuscript.

Funding: This research was funded by the Federal Ministry of Food and Agriculture of Germany (BMEL) based on a decision of the Parliament of the Federal Republic of Germany via the Federal Office for Agriculture and Food (BLE) under the innovation support program (Grant number: 2818201015).

Acknowledgments: The authors would like to thank Dorothee Pfirrmann who put a lot of organization and time on the data of both breeding locations and Stephan Glied-Olsen for data collection of the field trial of the Kleinhohenheim research station in 2017. We acknowledge the agricultural technical assistants of the Cropping Systems and Modelling group of the University of Hohenheim for their support during the field trials.

Conflicts of Interest: The authors declare no conflict of interest. The funders had no role in the design of the study; in the collection, analyses, or interpretation of data; in the writing of the manuscript, or in the decision to publish the results.

\section{Appendix A}

Table A1. Detailed information on the six conducted field trial in 2017 and 2018.

\begin{tabular}{|c|c|c|c|c|c|c|c|c|}
\hline Location & $\begin{array}{l}\text { Trial } \\
\text { Year }\end{array}$ & $\begin{array}{l}\text { Number of } \\
\text { Genotypes }\end{array}$ & $\begin{array}{l}\text { Plot Size } \\
\left(\mathrm{m}^{2}\right)\end{array}$ & $\begin{array}{c}\text { Field } \\
\text { Design }\end{array}$ & $\begin{array}{l}\text { Number } \\
\text { of Rows }\end{array}$ & $\begin{array}{l}\text { Number of } \\
\text { Columns }\end{array}$ & $\begin{array}{l}\text { Number of } \\
\text { Blocks }\end{array}$ & $\begin{array}{c}\text { Number of } \\
\text { Replications }\end{array}$ \\
\hline \multirow{2}{*}{$\begin{array}{l}\text { De Beersche } \\
\text { Hoeve (NL) }\end{array}$} & 2017 & 30 & 9 & row-column & 3 & 10 & 3 & 3 \\
\hline & 2018 & 16 & 9 & $\begin{array}{c}\text { randomized } \\
\text { complete } \\
\text { block }\end{array}$ & - & - & 3 & 3 \\
\hline \multirow{2}{*}{$\begin{array}{l}\text { Horticulture } \\
\text { station Heinze } \\
\text { (DE) }\end{array}$} & 2017 & 30 & 8.75 & $\begin{array}{l}\text { randomized } \\
\text { complete } \\
\text { block }\end{array}$ & - & - & 3 & 3 \\
\hline & 2018 & 16 & 8.75 & $\begin{array}{c}\text { randomized } \\
\text { complete } \\
\text { block }\end{array}$ & - & - & 3 & 3 \\
\hline \multirow{2}{*}{$\begin{array}{l}\text { Klein-hohenheim } \\
\text { (DE) }\end{array}$} & 2017 & 40 & 14 & row-column & 4 & 10 & 3 & 3 \\
\hline & 2018 & 36 & 14 & $\begin{array}{l}\text { non-resolvable } \\
\text { block }\end{array}$ & - & - & 12 & $\begin{array}{c}\text { unequal } \\
\text { replication }\end{array}$ \\
\hline
\end{tabular}

${ }^{1}$ In case of four genotypes, six replications were applied and the other 32 genotypes were replicated three times.

\section{References}

1. Illert, S.; Rampold, C. Die kleine marktstudie: Bio-gemuese. Gemuese 2018, 14, 52-54.

2. Quetsch, J. Der verzehr monitor: Rote bete. Gemuese 2019, 9, 56. 
3. Statistisches Bundesamt. Anbauflächen und Erntemengen von ökologisch angebautem Gemüse. Available online: https://www.destatis.de/DE/Themen/Branchen-Unternehmen/Landwirtschaft-ForstwirtschaftFischerei/Obst-Gemuese-Gartenbau/Tabellen/oekologisches-gemuese.html (accessed on 12 May 2020).

4. Kalloo, G.; Bergh, B. Genetic Improvement of Vegetable Crops; Kalloo, G., Bergh, B., Eds.; Pergamon Press Ltd.: Oxford, UK, 1993.

5. Clifford, T.; Howatson, G.; West, D.J.; Stevenson, E.J. The potential benefits of red beetroot supplementation in health and disease. Nutrients 2015, 7, 2801-2822. [CrossRef] [PubMed]

6. Dikeman, M.; Devine, C. Encyclopedia of Meat Sciences: 3-Volume Set; Academic Press: London, UK, 2014. [CrossRef]

7. Szopińska, A.A.; Gawęda, M. Comparison of yield and quality of red beet roots cultivated using conventional, integrated and organic method. J. Hortic. Res. 2013, 21, 107-114. [CrossRef]

8. Zaki, H.E.M.; Takahata, Y.; Yokoi, S. Analysis of the morphological and anatomical characteristics of roots in three radish (Raphanus sativus) cultivars that differ in root shape. J. Hortic. Sci. Biotechnol. 2012, 87, 172-178. [CrossRef]

9. Iwata, H.; Niikura, S.; Matsuura, S.; Takano, Y.; Ukai, Y. Evaluation of variation of root shape of japanese radish (Raphanus sativus, L.) based on image analysis using elliptic fourier descriptors. Euphytica 1998, 102, 143-149. [CrossRef]

10. Bavec, M.; Turinek, M.; Grobelnik-Mlakar, S.; Slatnar, A.; Bavec, F. Influence of industrial and alternative farming systems on contents of sugars, organic acids, total phenolic content, and the antioxidant activity of red beet (Beta vulgaris, L. Ssp. vulgaris Rote Kugel). J. Agric. Food Chem. 2010, 58, 11825-11831. [CrossRef]

11. Worthington, V. Nutritional quality of organic versus conventional fruits, vegetables, and grains. J. Altern. Complement. Med. 2001, 7, 161-173. [CrossRef]

12. Bourn, D.; Prescott, J. A comparison of the nutritional value, sensory qualities, and food safety of organically and conventionally produced foods. Crit. Rev. Food Sci. Nutr. 2002, 42, 1-34. [CrossRef]

13. Rembiałkowska, E. Quality of plant products from organic agriculture. J. Sci. Food Agric. 2007, 87, $2757-2762$. [CrossRef]

14. Velimirov, A.; Huber, M.; Lauridsen, C.; Rembiałkowska, E.; Seidel, K.; Bügel, S. Feeding trials in organic food quality and health research. J. Sci. Food Agric. 2010, 90, 175-182. [CrossRef] [PubMed]

15. Rembialkowska, E. Wholesomeness and Sensory Quality of the Potatoes and Selected Vegetables from the Organic Farms. Ph.D. Thesis, Warsaw Agricultural University, Krakow, Poland, 2000.

16. Lammerts Van Bueren, E.T.; Struik, P.C.; Tiemens-Hulscher, M.; Jacobsen, E. Concepts of intrinsic value and integrity of plants in organic plant breeding and propagation. Crop Sci. 2003, 43, 1922-1929. [CrossRef]

17. Goksoy, A.T.; Turkec, A.; Turan, Z.M. Determination of some agronomic characteristics and hybrid vigor of new improved synthetic varieties in sunflower (Helianthus annuus, L.). Helia 2002, 25, 119-130. [CrossRef]

18. Torricelli, R.; Ciancaleoni, S.; Negri, V. Performance and stability of homogeneous and heterogeneous broccoli (Brassica oleracea, L. Var. italica Plenck) varieties in organic and Low-Input conditions. Euphytica 2014, 199, 385-395. [CrossRef]

19. Petronienė, O.D. Inheritance of red beetroot yield and morphological features Pdf. Sodinink. Daržinink. 2005, 24, 163-170.

20. Sahamishirazi, S.; Moehring, J.; Zikeli, S.; Fleck, M.; Claupein, W.; Graeff-Hoenninger, S. Graeff-Hoenninger, S. Agronomic performance of new open pollinated experimental lines of broccoli (Brassica oleracea, L. Var. italica) evaluated under organic farming. PLoS ONE 2018, 13, e0196775. [CrossRef]

21. Khan, N.U. F1 Hybrid. In Reference Module in Life Sciences; Elsevier: Amsterdam, The Netherlands, 2017. [CrossRef]

22. Wang, M.; Goldman, I.L. Phenotypic variation in free folic acid content among F1 Hybrids and Open-Pollinated cultivars of red beet. J. Am. Soc. Hortic. Sci. 1996, 121, 1040-1042. [CrossRef]

23. Piepho, H.P. An algorithm for a Letter-Based representation of All-Pairwise comparisons. J. Comput. Graph. Stat. 2004, 13, 456-466. [CrossRef]

24. Rubóczki, T.; Raczkó, V.; Takácsné Hájos, M. Evaluation of morphological parameters and bioactive compounds in different varieties of beetroot (Beta vulgaris, L. Ssp. esculenta GURKE Var. rubra L.). Int. J. Hortic. Sci. 2015, 21, 31-35. [CrossRef]

25. Goldman, I.L. Differential effect of population density on shape and size of cylindrical red beet (Beta vulgaris, L.) genotypes. J. Am. Soc. Hortic. Sci. 1995, 120, 906-908. [CrossRef] 
26. Kikkert, J.R.; Reiners, S.; Gugino, B.K. Row width, population density, and harvest date effects on marketable yield of table beet. Horttechnology 2010, 20, 560-567. [CrossRef]

27. Feller, C.; Fink, M. Nitrate content, soluble solids content, and yield of table beet as affected by cultivar, sowing date and nitrogen supply. HortScience 2004, 39, 1255-1259. [CrossRef]

28. El-Tantawy, E.M.; Eisa, G.S.A. Growth, yield, anatomical traits and betanine pigment content of table beet plants as affected by nitrogen sources and spraying of some nutrients. J. Appl. Sci. Res. 2009, 5, 1173-1184.

29. Stagnari, F.; Galieni, A.; Speca, S.; Pisante, M. Water stress effects on growth, yield and quality traits of red beet. Sci. Hortic. Amst. 2014, 165, 13-22. [CrossRef]

30. Pfiffner, L.; Niggli, U.; Velimirov, A.; Boltzmann, L.; Balzer, U.; Balzer, F.; Besson, J.M. Effect of three farming systems (Bio-Dynamic, Bio-Organic, Conventional) on yield and quality of beetroot (Beta vulgaris, L. Var. Esculenta, L.) in a seven year crop rotation. In Proceedings of the Workshop on Ecological Aspects of Vegetable Fertilization in Integrated Crop Production in the Field, Waedenswil, Switzerland, 1 August 1993; ISHS Acta Horticulturae 339: Leuven, Belgium, 1993; pp. 11-32. [CrossRef]

31. Takácsné Hájos, M.; Rubóczki, T. Effects of environmental factors on morphological and quality parameters of table beet root. Int. J. Hortic. Sci. 2012, 18, 139-146. [CrossRef]

32. Akhiyarov, B.; Ismagilov, R.; Islamgulov, D.; Kuznetsov, I.; Akhiyarova, L.; Abdulvaleev, R.; Alimgafarov, R.; Pavlov, A.; Valitov, A.; Sergeev, V. Yield and quality of table beet depending on cultivation technology elements. J. Eng. Appl. Sci. 2018, 13, 8752-8759.

33. Wruss, J.; Waldenberger, G.; Huemer, S.; Uygun, P.; Lanzerstorfer, P.; Müller, U.; Höglinger, O.; Weghuber, J. Compositional characteristics of commercial beetroot products and beetroot juice prepared from seven beetroot varieties grown in upper Austria. J. Food Compos. Anal. 2015, 42, 46-55. [CrossRef]

34. Ijoyah, M.; Sophie, V.; Rakotomavo, H. Yield performance of four beetroot (Beta vulgaris, L.) varieties compared with the local variety under open field conditions in seychelles. Agro-Science 2008, 7, 139-142. [CrossRef]

35. Ugrinovic, K. Effect of nitrogen fertilization on quality and yield of red beet (Beta vulgaris Var Conditiva Alef.). In Proceedings of the International Workshop on Ecological Aspects of Vegetable Fertilization in Integrated Crop Production, Wellesbourne, Warwick, UK, 1 December 1999; ISHS Acta Horticulturae 506: Leuven, Belgium, 1999; pp. 99-104. [CrossRef]

36. Salter, P.J.; Currah, I.E.; Fellows, J.R. Studies on some sources of variation in carrot root weight. J. Agric. Sci. 1981, 96, 549-556. [CrossRef]

37. Irving, D.; Boulton, A.; Wade, S. Beetroot Stand Management; New South Wales Department of Primary Industries, Yanco Agricultural Institute, Bathurst Primary Industries Centre, Project Number: VG06117; Horticulture Australia Ltd.: Sydney, Australia, 2000.

38. Barański, R.; Grzebelus, D.; Frese, L. Estimation of genetic diversity in a collection of the garden beet group. Euphytica 2001, 122, 19-29. [CrossRef]

39. Watson, J.F.; Goldman, I.L. Inheritance of a gene conditioning blotchy root color in table beet (Beta vulgaris, L.). J. Hered. 1997, 88, 540-543. [CrossRef]

40. Goldman, I.L.; Navazio, J.P. History and breeding of table beet in the United States. In Plant Breeding Reviews; Janick, U., Ed.; John Wiley \& Sons, Inc.: Hoboken, NJ, USA, 2010; Volume 22, pp. 357-388. [CrossRef]

41. Da Silva, G.O.; De Souza, V.Q.; Pereira, A.D.S.; De Carvalho, F.I.F.; Neto, R.F. Early generation selection for tuber appearance affects potato yield components. Crop. Breed. Appl. Biotechnol. 2006, 6, 73-78. [CrossRef]

42. Jacobsohn, R.; Zutra, D.; Dan, H.; Kelman, Y. Studies of carrot cavity spot. J. Hortic. Sci. 1984, 59, 529-535. [CrossRef]

43. Faraji, M.; Amirian Chakan, A.; Jafarizadeh, M.; Mohammadian, B.A. Soil and nutrient losses due to root crops harvesting: A case study from southwestern Iran. Arch. Agron. Soil Sci. 2017, 63, 1523-1534. [CrossRef]

44. Iwata, H.; Niikura, S.; Matsuura, S.; Takano, Y.; Ukai, Y. Interaction between genetic effects and soil type in diallel analysis of root shape and size of Japanese radish (Raphanus sativus L.). Breed. Sci. 2004, 54, 313-318. [CrossRef]

45. Villordon, A.; Carroll, H. Digital image analysis of sweetpotato storage roots in herbicide trials. HortScience 2002, 37, 669-670. [CrossRef]

46. Stephen Nottingham's meticulously researched online book, Beetroot. Available online: https://www. academia.edu/21542519/Beetroot (accessed on 7 June 2020). 
47. Advisory Committee on Vegetable Crops. Beets (Red). Available online: https://www.faa.gov.nl.ca/agrifoods/ plants/veg_listing.html (accessed on 25 November 2019).

48. Lapwood, D.H.; Adams, M.J.; Crisp, A.F. The susceptibility of red beet cultivars to streptomyces scab. Plant. Pathol. 1976, 25, 31-33. [CrossRef]

49. Strang, J.; Lentz, A.P.; Smigell, C.; Sigler, P.; Seebold, K.; Slone, D. Beet Variety Evaluation; University of Kentucky: Lexington, KY, USA, 2009.

50. Wolyn, D.J.; Gabelman, W.H. Selection for betalain pigment concentrations and total dissolved solids in red table beets. J. Am. Soc. Hortic. Sci. 2019, 115, 165-169. [CrossRef]

51. Khan, A.A.; Peck, N.H.; Taylor, A.G.; Samimy, C. Osmoconditioning of beet seeds to improve emergence and yield in cold soil1. Agron. J. 1983, 75, 788-794. [CrossRef]

52. Taylor, A.G.; Goffinet, M.C.; Pikuz, S.A.; Shelkovenko, T.A.; Mitchell, M.D.; Chandler, K.M.; Hammer, D.A. Physico-Chemical factors influence beet (Beta vulgaris, L.) seed germination. In The Biology of Seeds: Recent Research Advances; Nicolas, G., Bradford, K.J., Come, D., Pritchard, H.W., Eds.; CABI: Wallingford, UK, 2003; pp. 433-440.

53. Tanumihardjo, S.A.; Suri, D.; Simon, P.; Goldman, I.L. Vegetables of temperate climates: Carrot, parsnip and beetroot. In Encyclopedia of Food and Health; Elsevier Ltd.: Amsterdam, The Netherlands, 2015; pp. 387-392. [CrossRef]

54. Griepentrog, H.W.; Olsen, J.M.; Weiner, J.; Vdi, M.E.G. The Influence of row width and seed spacing on uniformity of plant spatial distributions. In Proceedings of the 67th International Conference on Agricultural Engineering (Land-Technik AgEng2009)-Innovations to Meet Future Challenges, Hannover, Germany, 6-7 November 2009; pp. 265-270.

(C) 2020 by the authors. Licensee MDPI, Basel, Switzerland. This article is an open access article distributed under the terms and conditions of the Creative Commons Attribution (CC BY) license (http://creativecommons.org/licenses/by/4.0/). 